DOI 10.18699/SBB-2020-86

\title{
Проект создания геномно-географического атласа автохтонных сортов винограда России
}

Федосов Д.Ю.

НИЦ «Курчатовский институт», Москва, Россия

e-mail: Fedosov_DY@nrcki.ru

Ключевые слова: виноград, геном, автохтонные сорта

Мотивация и иель: Несмотря на принадлежность к одному к виду, высокая степень генетического полиморфизма обуславливает огромное разнообразие сортов винограда Vitis vinifera. Первая сборка генома V. vinifera (сорт Пино нуар) была опубликована в 2007 году [1], подобные работы позволяют по-новому подходить к генотипированию и классификации сортов и их семейств. Так, анализ сборки бургундского сорта Шардоне показал, что размер его генома превышает размер генома близкородственного сорта Пино нуар более чем на 20\% [2]. Это подчеркивает необходимость получения независимых геномных сборок сортов более чем 140 российских автохтонных сортов винограда.

Meтоды и алгоритмы: Планируется получить высококачественные геномные сборки ключевых автохтонных российских сортов винограда, которые будут использоваться как референсные при генотипировании других. Планируется использовать гибридную сборку, полученную комбинированием технологий высокопараллельного секвенирования - одномолекулярного секвенирования Oxford Nanopore и технологий коротких прочтений (BGI и/или Illumina). Это позволит с высокой точностью оценить как однонуклеотидные полиморфизмы, так и крупные структурные перестройки. В реализации стратегии планируется задействовать наработки по генотипированию автохтонных сортов специалистов ФГБУН «ВННИИВиВ «Магарач» РАН» (Ялта) и СКЗНИИСВиВ (Краснодар).

Результаты: В течение 2020 года будут получены высококачественные геномные сборки сортов Красностоп золотовский и Кокур белый. Дальнейшие этапы включают геномную идентификацию, отделение возможных повторов и клонов, секвенирование других сортов.

Заключение u доступность: При помощи биоинформатического анализа нуклеотидных полиморфизмов и анализа сегментов, идентичных по происхождению (identity-by-descent), будет построена карта филогенеза автохтонных российских сортов, выявлены ключевые группы, генетически детерминированы ведущие сортовые признаки. Планируемый геномногеографический атлас будет включать данные метаболомики сортов, истории, географии, ампелографии и энологии.

Благодарности: Работа выполняется на основании Соглашения с Минобрнауки РФ № 075-15-20191659 от 31.10.2019.

\section{Список литературы}

1. Velasco R. et al. A high quality draft consensus sequence of the genome of a heterozygous grapevine variety. PLoS ONE. 2: e1326 (2007).

2. Zhou et al. The population genetics of structural variants in grapevine domestication. Nature Plants. V. 5, P. $965-979$ (2019). 